\title{
History of conservation and research activities of the Eurasian beaver (Castor fiber) in the Voronezhsky Nature Reserve
}

\author{
Natalya B. Romashova
}

\begin{abstract}
This article provides a brief historical overview of research and management activities at the Voronezhsky Nature Reserve, Russia, and its role in the successful recovery of Eurasian beaver (Castor fiber) populations. I documented the various stages and actions for their protection, live-capture and release of Eurasian beavers from the 1930s to the 1980s. This review includes a list of several scientific studies conducted in the Voronezhsky Nature Reserve related to the biology and ecology of beavers, the development of a captive-breeding program, and research into specific diseases and parasites. Many of the materials for this study are key bibliographical references of the scientific publications found in the Proceedings of the Reserve.
\end{abstract}

KEY WORDS: Voronezhsky Nature Reserve, Eurasian beaver, protection, catching, release, nursery.

Natalya B. Romashova [bvnrom@rambler.ru], Voronezhsky State Nature Biosphere Reserve, Voronezh 394080, Russia.

\section{История сохранения и изучения бобра (Castor fiber) в Воронежском заповеднике}

\begin{abstract}
Н.Б. Ромашова
РЕЗЮМЕ. Дан краткий исторический очерк деятельности Воронежского заповедника в связи с работами по восстановлению численности евразийского бобра Castor fiber. Отмечены основные этапы и мероприятия по охране, отлову и расселению бобров в 1930-1980-е гг. Перечислены проведенные в Воронежском заповеднике основные исследования по биологии и экологии, развитию клеточного боброводства, а также по болезням и паразитам бобров. Приведен библиографический список основных научных публикаций в Трудах заповедника.
\end{abstract}

КЛЮЧЕВЫЕ СЛОВА: Воронежский заповедник, евразийский бобр, охрана, отлов, расселение, бобровый питомник.

\section{Introduction}

On the cusp of the 20th and 21 st centuries the Eurasian beaver was on the verge of extinction in Eurasia (Halley \& Rosell, 2002; Halley et al., 2012). This species was almost extirpated as a result of illegal hunting and trapping, mainly because of the valuable fur and use of castoreum. Small colonies of beavers of the Castor genus remained on the Eurasian continent, although only in few isolated areas. Within the former Soviet Union (USSR) there were six areas inhabited by beavers. The total population of beavers in the USSR at that time did not exceed 1,000 animals (Zharkov, 1960).

Comprehensive studies of the beaver and activities specific to its protection started in our country in 1920s. The state developed a four-part plan for preservation of the beavers. Firstly, countrywide prohibition of hunting for beavers was one of the first effective measures at the state level. The second important step for the protection and restoration of the population was establishment of reserves, which resulted in the complete withdrawal of economic activities from these natural areas. The first state "beaver" reserves were found in locations where native colonies of beavers remained. Consequently, in 1923 the Voronezhsky Nature Reserve was established. Similarly, the Berezinsky Nature Reserve in Belarus and the Kondo-Sosvinsky Nature Reserve in Western Siberia were created in 1925 and 1927, respectively. In other parts of the country, local wildlife areas were organized for beaver protection. Countrywide ban of hunting and the creation of reserves led to rapid growth in the number and size of beaver colonies. The third phase of restoration of the former habitat and population was artificial (forced) resettlement of beavers in 1934. These activities were associated with selective capture of animals in native populations and resettlement of beavers in the country and elsewhere in Eurasia.

An expedition of Moscow scientists under the guidance of zoologist Sergei I. Ognev from 1919 to 1922 found a few colonies of the Eurasian beaver on small rivers in the Voronezh Province: Usman, Ivnitsa and Voronezh. The total number of animals was approximately 50. According to the results of the expedition, scientists asked state authorities to create a reserve in 


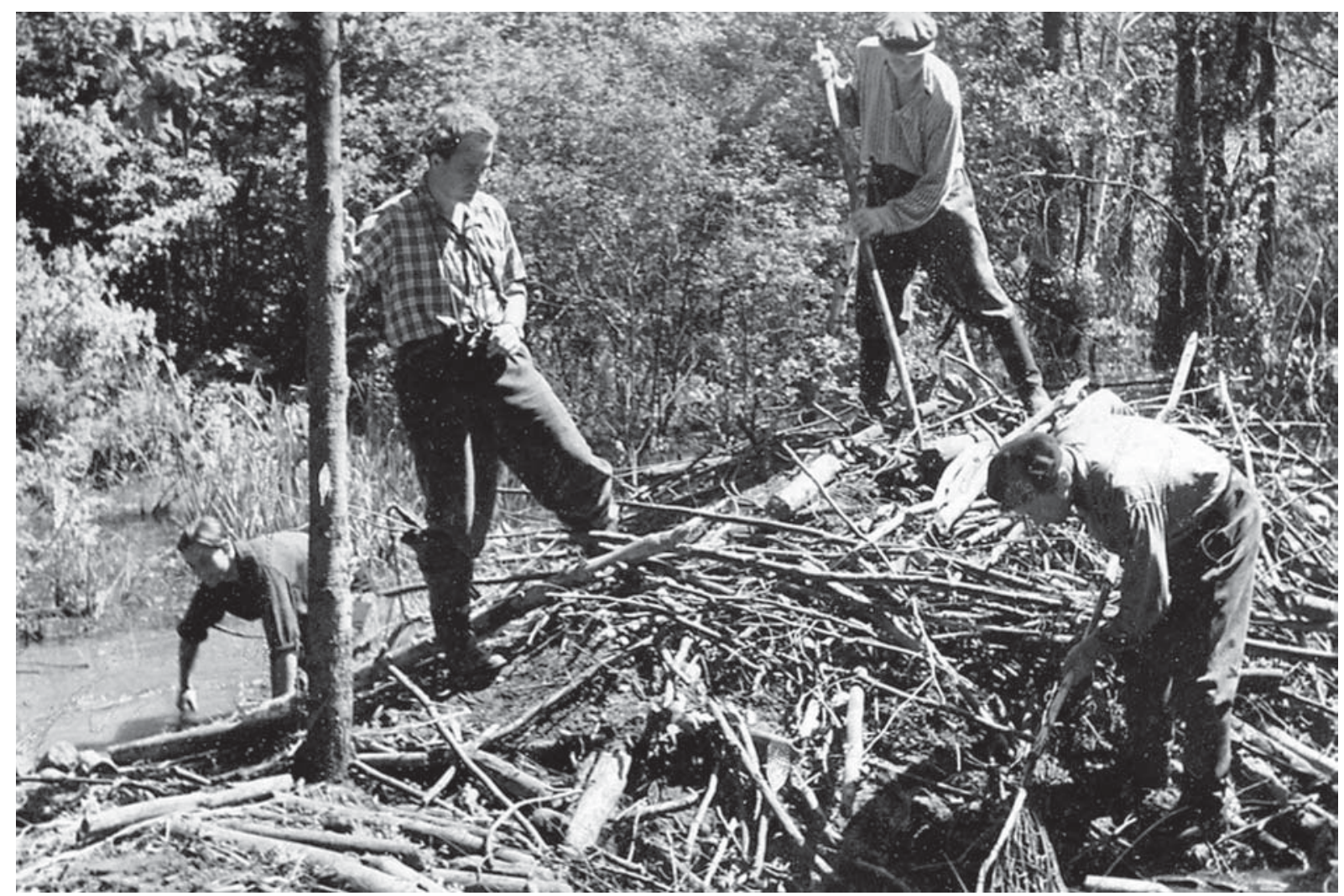

Fig. 1. Beaver trapping, 1930s. This photo and those that follow are from the archives of the Voronezhsky Nature Reserve.

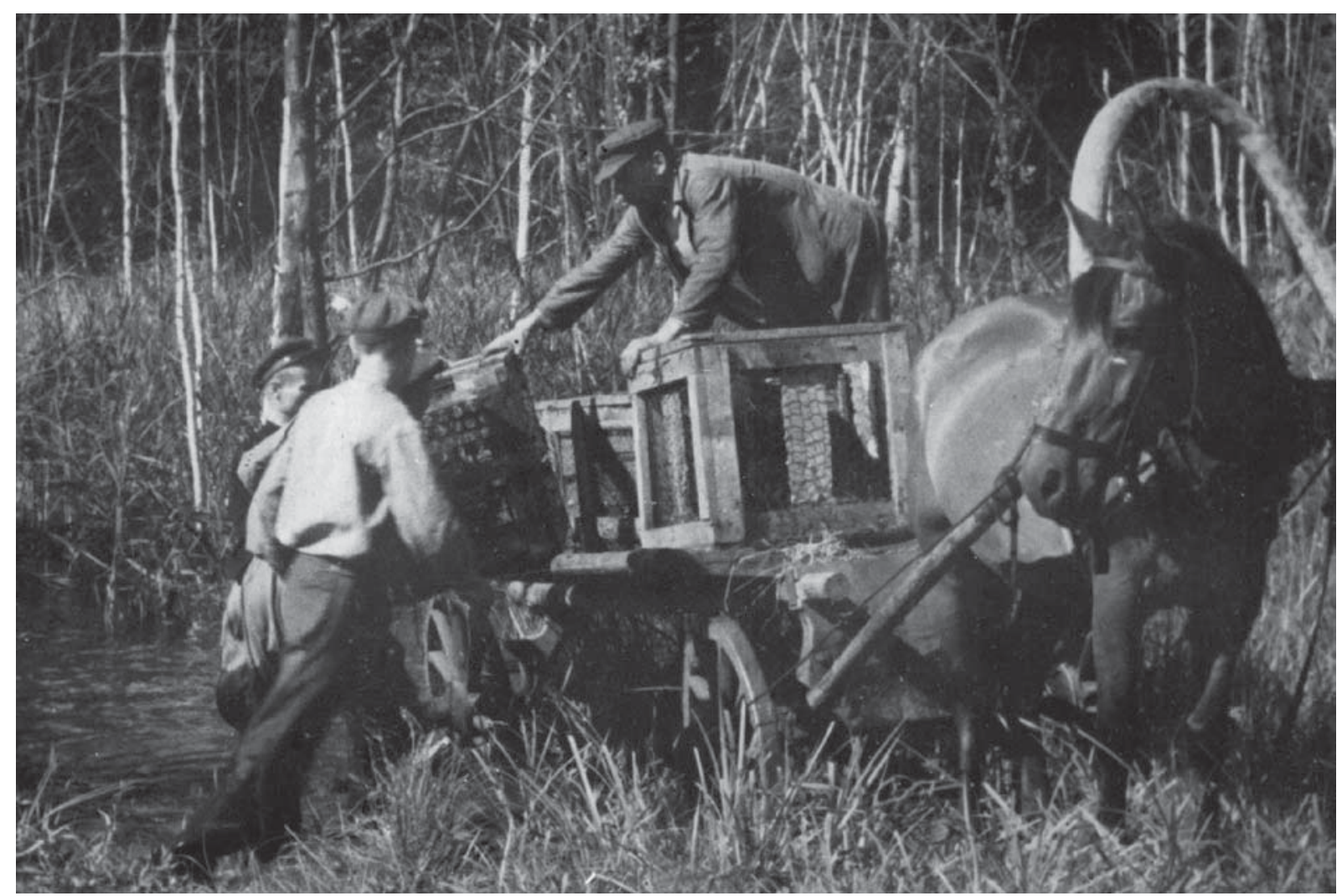

Fig. 2. Beaver trapping and transportation, 1930s. 


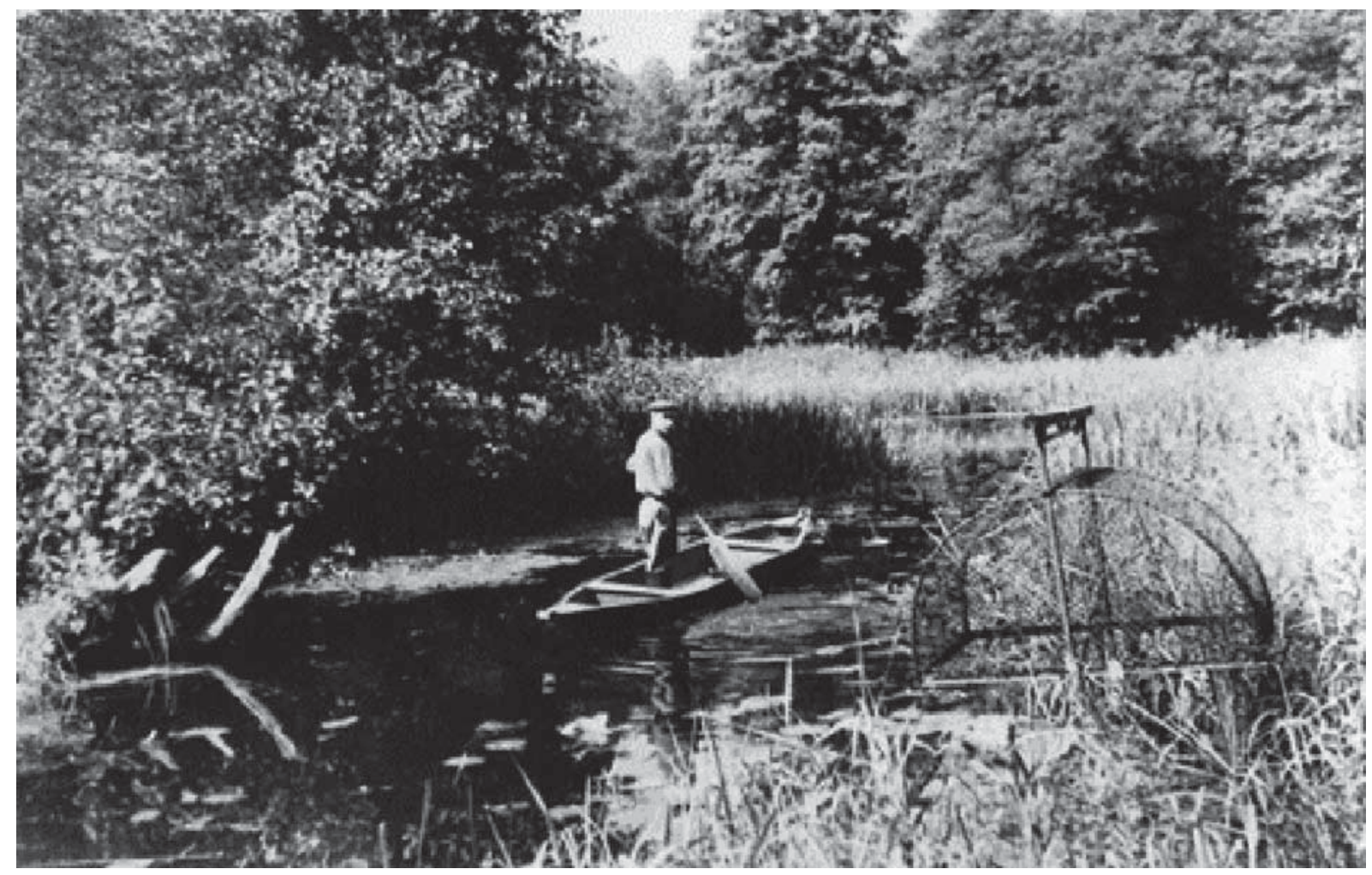

Fig. 3. Use of special traps.

this area to protect this valuable species. Voronezh Provincial Forestry Department approved the State Nature Reserve for beavers along the Usman River on December 3, 1923. The area of the reserve at the time of its establishment was 2,496 hectares. A staff of eight people was approved for the protection and management of the new reserve. In 1934, the territory of the reserve was increased to 31,043 hectares. Protection measures contributed to an increased number of beavers. The 456 beavers were registered on the territory of the reserve according to "The chronicle of nature" in 1934. The main task of the reserve was protection and restoration of beaver populations in natural habitats of Russia. The Voronezhsky Nature Reserve became the organizer and coordinator of these works throughout the country.

The second important step in preservation of the Eurasian beaver became its re-establishment in former habitats. The first comparable works were conducted in Western Europe in Scandinavian countries. From the 1920 to 1930s, beavers from Norway were released in Sweden, Latvia, and Finland. The resettlement of beavers in the Soviet Union and in other countries was of a large scale. Initially, the only supplier of breeding material was the Voronezhsky Nature Reserve. The first translocations of Voronezh beavers was an initial group of eight animals. These beavers were sent to Lapland Biosphere Reserve in 1934. From 1934 to 1947, the beavers from the Voronezhsky Nature Reserve were settled in 15 regions including eight nature reserves:
Lapland, Central Forest, Mordovian, Khoper, Oka, Pechora-Ilych, Klyazma and Zhuvintas (Zharkov, 1966). Beginning in 1948, Belarusian endemic populations of beavers were also used for reintroduction programs. Some secondary colonies from nature reserves in which beavers successfully re-colonized, also became a source of breeding material for reintroductions.

The most significant achievements in the translocations of beavers were during the 1950s and 1960s. Beavers from the Soviet Union were introduced into other countries. In 1948, thirty beavers were released in Poland. In 1958, eight more beavers were sent to Popielno (Poland) for the creation of a beaver farm. In 1953, thirty beavers were released in Germany and, in 1962, Voronezh beavers were released into Mongolia.

The capture and release of beavers from the Voronezhsky Nature Reserve continued until 1977. Approximately 3,000 beavers were taken from the reserve to 52 regions of the USSR, as well as to Germany, Poland, and other European countries. The original mandate for the Voronezhsky Nature Reserve served as impetus for many studies in beaver biology. Most of studies were novel and were often exploratory in nature.

Practical measures to restore beaver population were accompanied by studies in three main areas:

1. Scientific substantiation of live-capture, husbandry, and transportation of beavers. Development of methods of recording and tagging of beavers, and their practical application. Scientific substantiation of biological aspects of areas where beavers were introduced. 


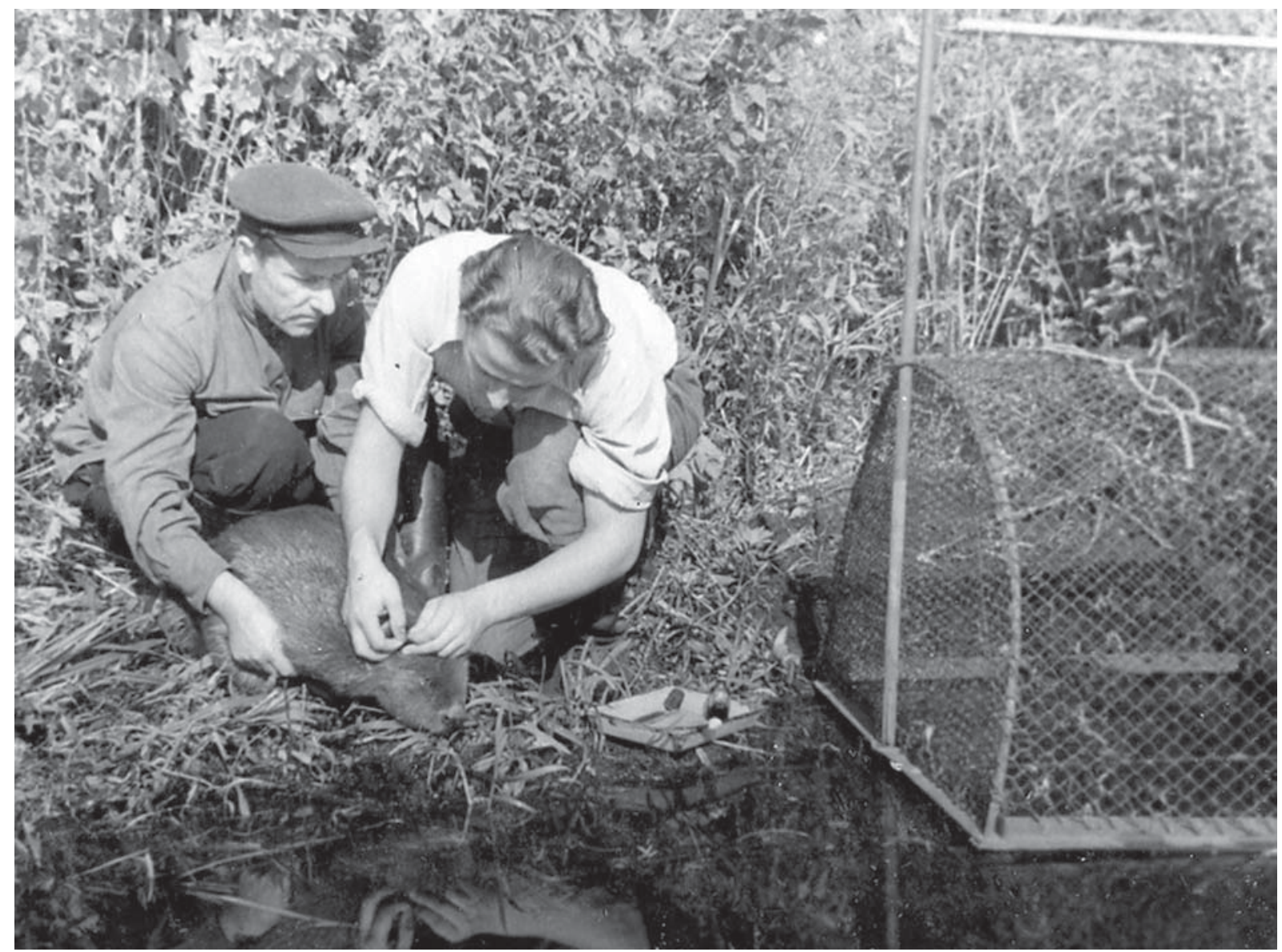

Fig. 4. Handling and tagging of wild beavers. 1930s.

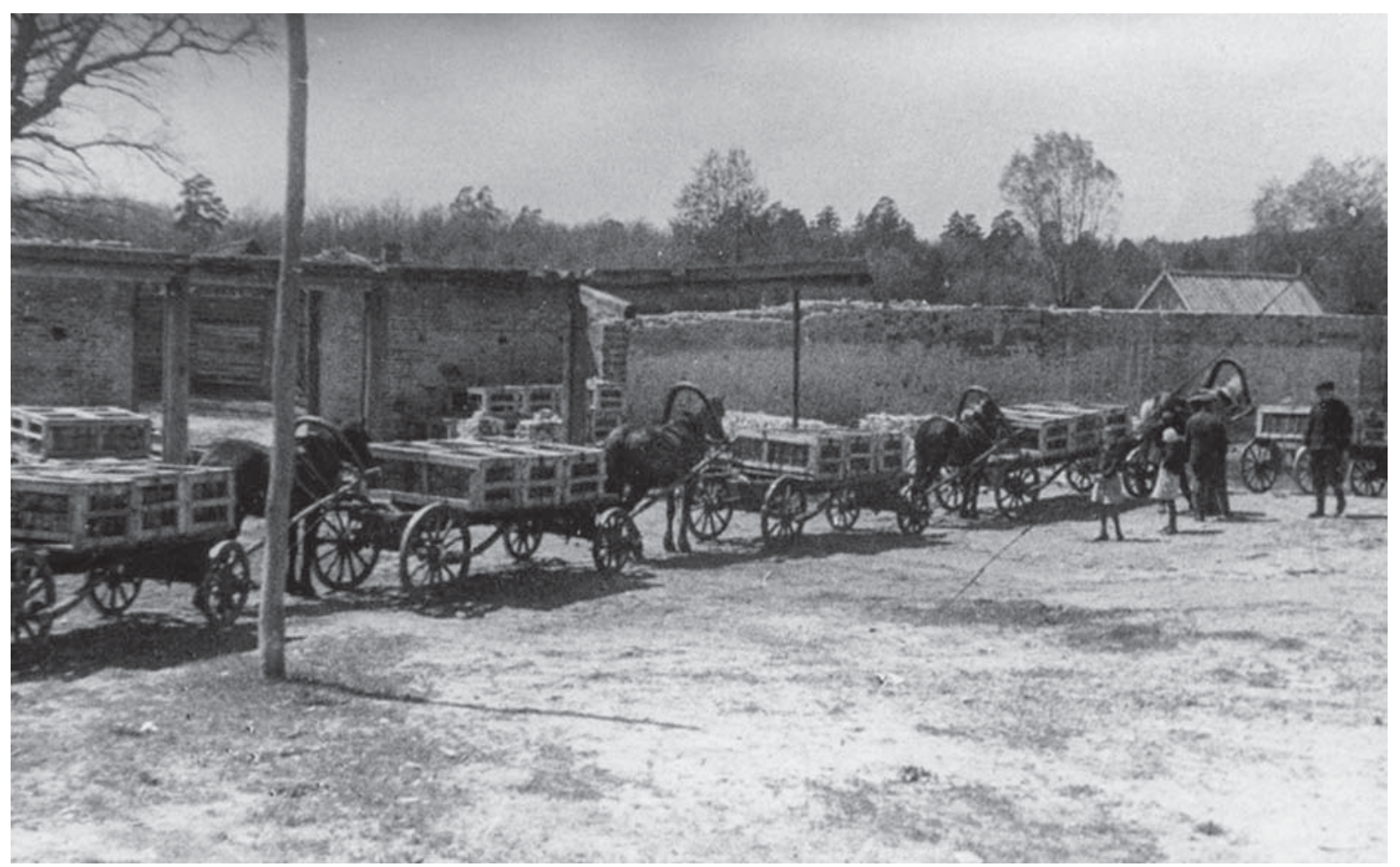

Fig. 5. Sending beavers for dispersal, 1930s. 


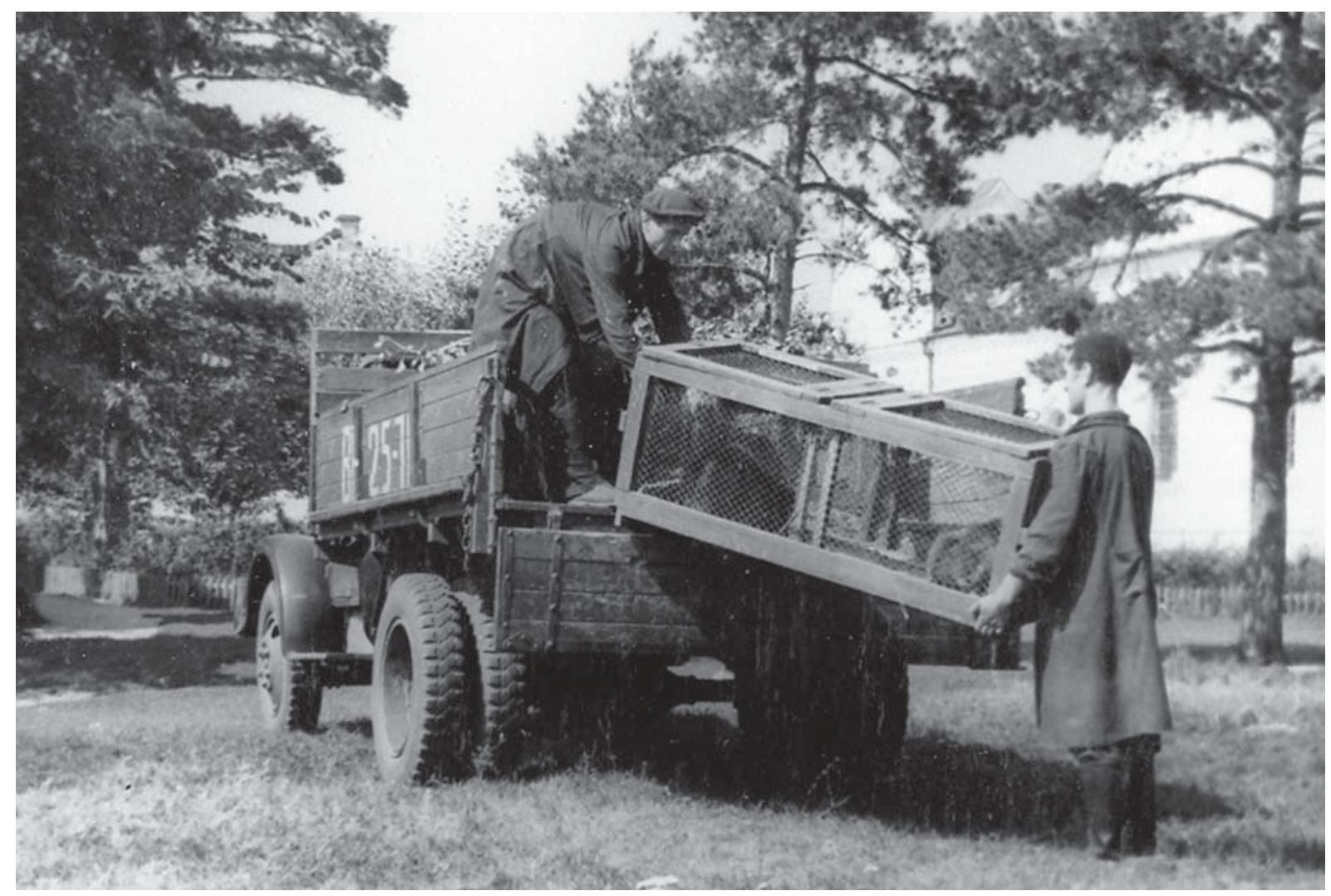

Fig. 6. Delivery of beaver for dispersal by motor transport, 1940s.

2. Development of a greater understanding of the science of beaver breeding and reproduction. Keeping and breeding of beavers in captivity (to perform these tasks, an experimental beaver nursery was founded in 1932 in the Voronezhsky Nature Reserve).

3 . Research related to the study of biology, physiology and anatomy of the beaver, its diseases and parasites.

\section{Capture, husbandry, and transportation} of beavers, development of methods for monitoring and tagging, biotechnology. Scientific substantiation of these measures

The first research into ecology of Eurasian beavers in Russia and an assessment of their population numbers began in 1928 by the first researchers at the Voronezhsky Nature Reserve: K.I. Kiselev and Z.I. Georgievskaya. At this time, the famous scientist, Wilhelm $\mathrm{K}$. Khlebovich, began his scientific research in the Reserve. His article "Data on the ecology of the Eurasian beaver in the Voronezhsky Reserve" was published in the first issue of the Proceedings of the Voronezhsky Nature Reserve in 1938. He first conducted a field survey of the Voronezh River basin with the aim of finding new colonies of beavers. He also assessed foraging areas in this territory. Khlebovich was the first person to study the inheritance of fur color in beavers. When studying beaver anatomy, he registered new species of parasitic worms specific to beavers. His scientific researches laid the foundation for the comprehensive study of the Eastern European beaver and its ecology (Khlebovich, 1938a, b, c).

The most significant contributions for live-capture, temporary holding, reintroduction, husbandry and breeding of beavers in captivity were made by scientists from the Voronezhsky Nature Reserve: Lavrov L.S., Poyarkov V.S., Zharkov I.V., Nikolaev A.G. and many other researchers. For the capture and reintroduction of beavers, they developed and successfully applied methods for monitoring and tagging, as well as methods for studying their colonies. L.S. Lavrov described humane methods for the live-capture of beavers, and their subsequent transportation and release into the wild. $\mathrm{He}$ proposed a method to quantify beavers by assessing the carrying capacity of beaver colonies. Also, Lavrov proposed a method of banding beavers in the wild. He codeveloped recommendations for conducting biotechnical actions among beavers (Lavrov, 1948a, 1953, 1956, 1969a, b; Lavrov \& Nikolaev, 1980; Nikolaev, 1980, 1997; and others).

Poyarkov V.S. developed a method of estimating the number of beavers relative to the volume of bark stripping. He offered and tested principles of organization for beaver farms and carrying out biological re- 


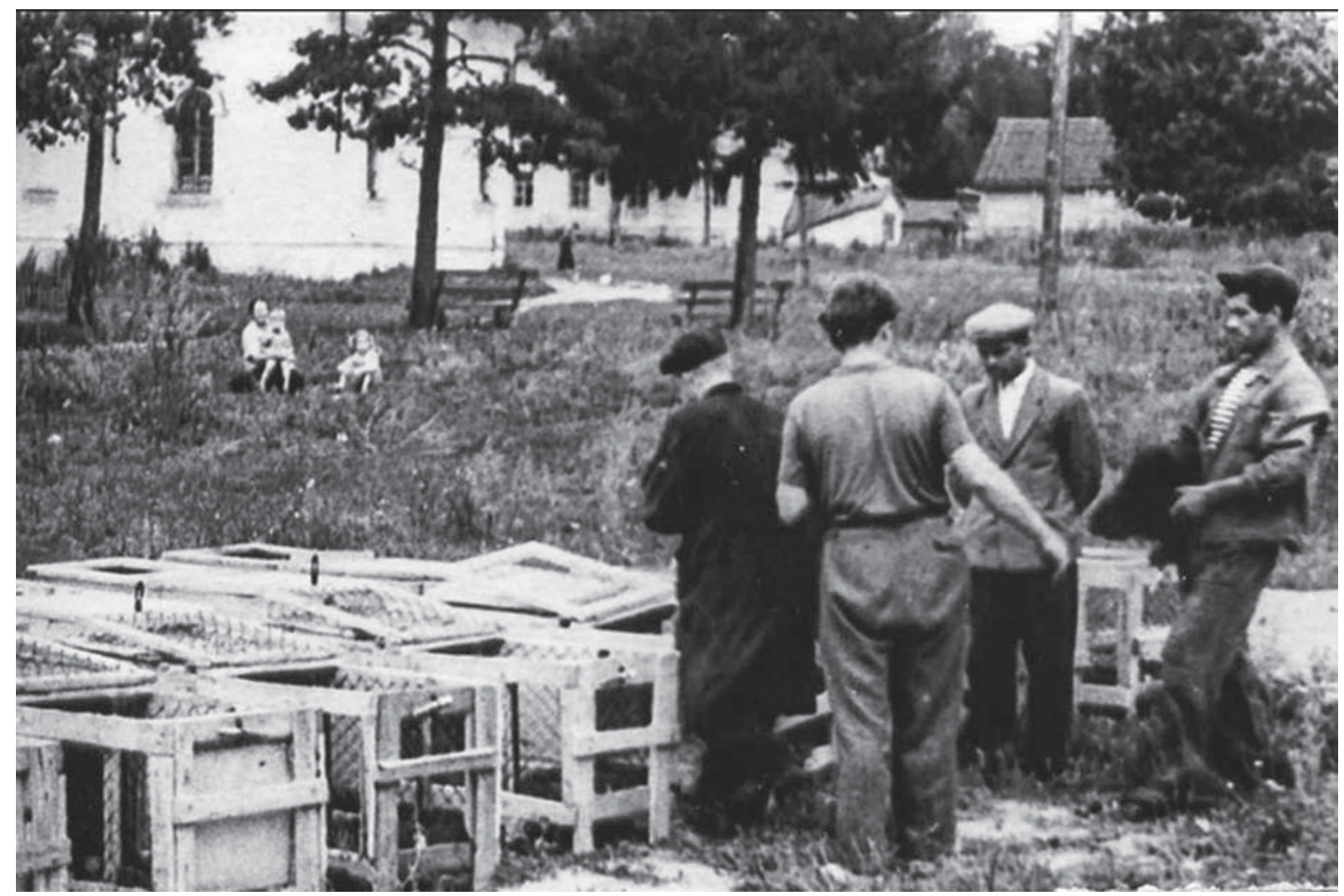

Fig. 7. Preparation of a group of beavers for dispersal in the country, the end of 1950s.

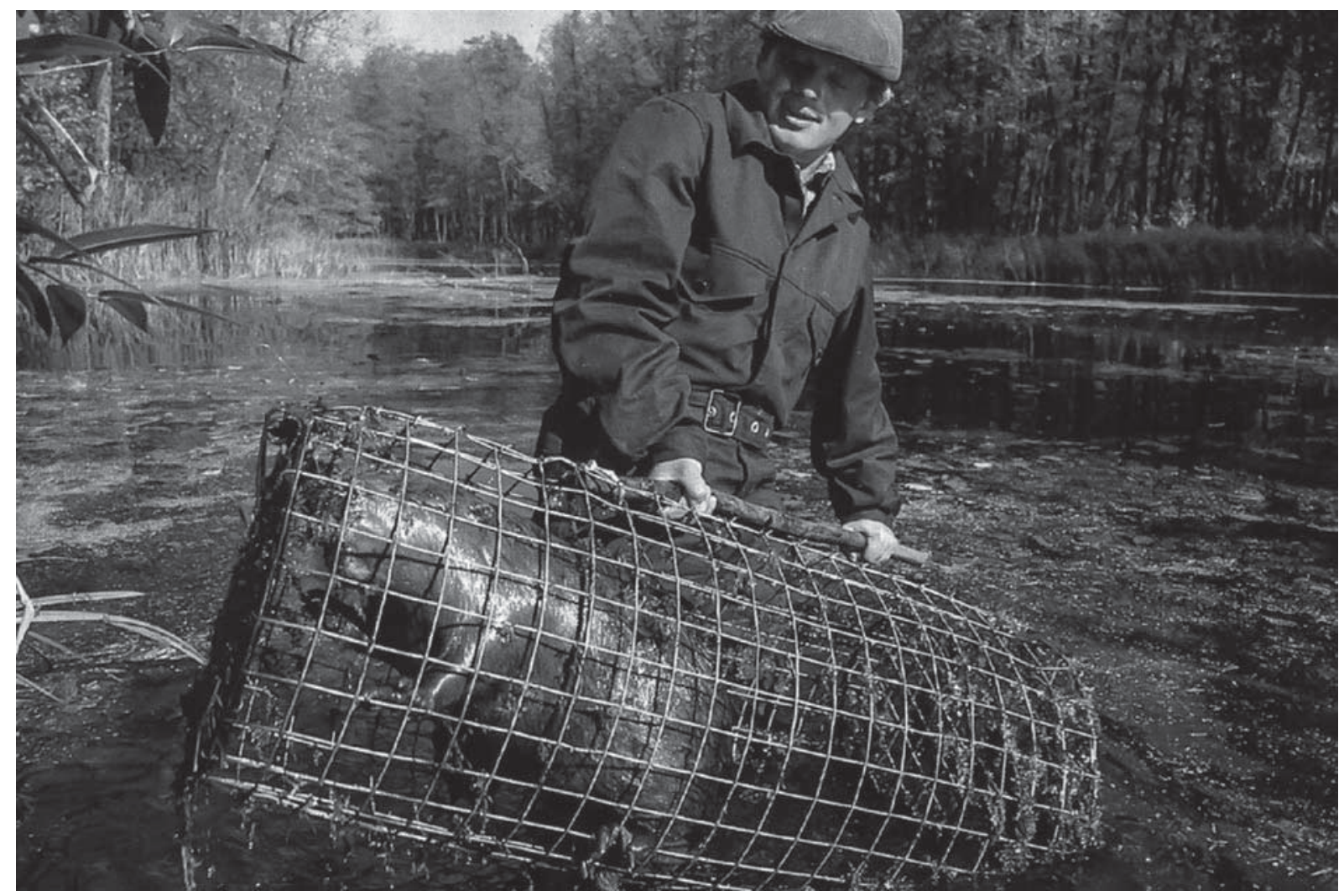

Fig. 8. Beaver in a trap. Zoologist A.G. Nikolaev, 1980s. 


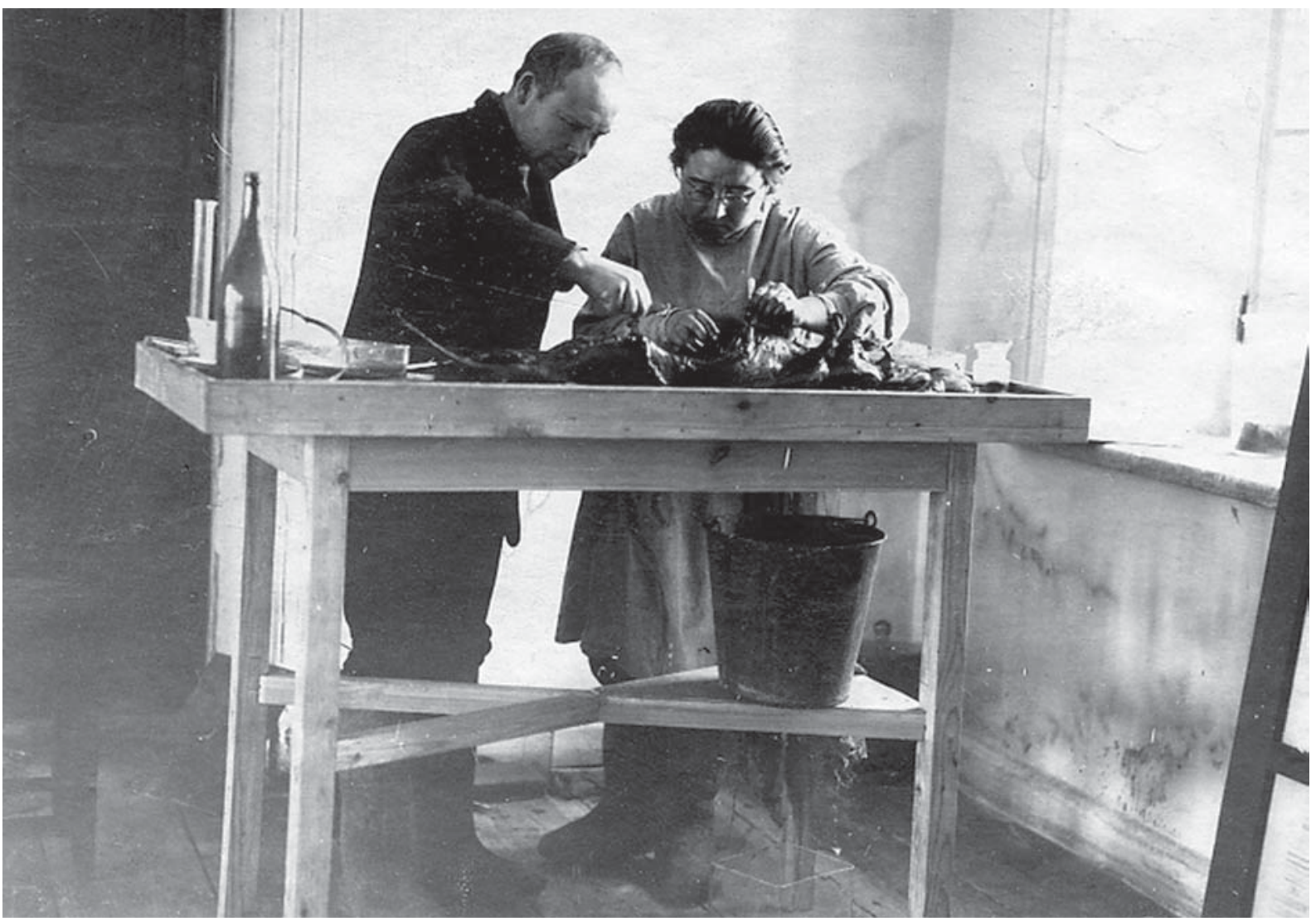

Fig. 9. Anatomical studies of the beaver - zoologist W.K. Khlebovich, laboratory assistant O.A. Yanushevich, 1930s.

search (Poyarkov, 1953). I.V. Zharkov, in the 1960s, headed the scientific department of the Voronezhsky Nature Reserve. He managed the enormous number of papers written about the beaver within the reserve. He developed a strategy for the reintroduction of beavers throughout many areas of the Soviet Union. He first suggested monitoring and enumerating beavers with the help of aviation. He also recommended ways to improve beaver habitats (Zharkov, 1956, 1960, 1969a, b, 1975). Based on these studies, scientists developed methods for assessing beaver habitats and the foraging capacity within these habitats. Zharkov also conducted habitat improvement projects in areas settled by beavers, by planting soft-wooded broadleaved trees, replanting willows, and cleaning reservoirs. Rangers were hired to catch beavers. They perfected methods for the live-capture of beavers by special live-traps. One of the most effective ways to protect beavers was the extermination of wolves. When settling beavers about the country, researchers purposefully established groups of beavers with a black color of fur in some places. Thus, the Pechoro-Ilych and Khoper populations were created.

While catching and reintroducing beavers, some studies into the biology, physiology, diseases and parasites of this species were conducted. V.A. Romashov was the first to develop and put into practice ways of dehelmintization of beavers at temporary holding ar- eas. These actions were required when moving beavers from the Voronezhsky Nature Reserve to other areas, and were recommended for application in other parts of the country (Romashov, 1960).

The success of reintroduction activities of Voronezh beavers was achieved because methods followed a comprehensive science-based approach. Scientists of the reserve (Dezhkin et al., 1960) developed various recommendations in their manuscript "Keeping, transportation and release of river beavers (a practical grant)". During the temporary captivity of beavers, there were bonds formed that created pair-bonds between beavers caught in wild. Such animals, when subsequently rereleased were found to adapt well to their new habitats. Altogether 2,757 wild-caught beavers passed through temporary holding facilities at the nursery during all the years the facility was in operation. In 1968, Zharkov I.V. was the first researcher in the Soviet Union who defended a doctoral dissertation about beavers at the Zoological Institute of the USSR Academy of Sciences: "Structure and dynamics of population of mammals on the example of the beaver in the USSR". In total, there were more than 20 dissertations were written at the Voronezhsky Nature Reserve, regarding beavers.. The results of long-term research work on beavers have been resulted in several monographs (Dyakov, 1975; Lavrov, 1981; Dezhkin et al., 1986; Romashov, 2015). 


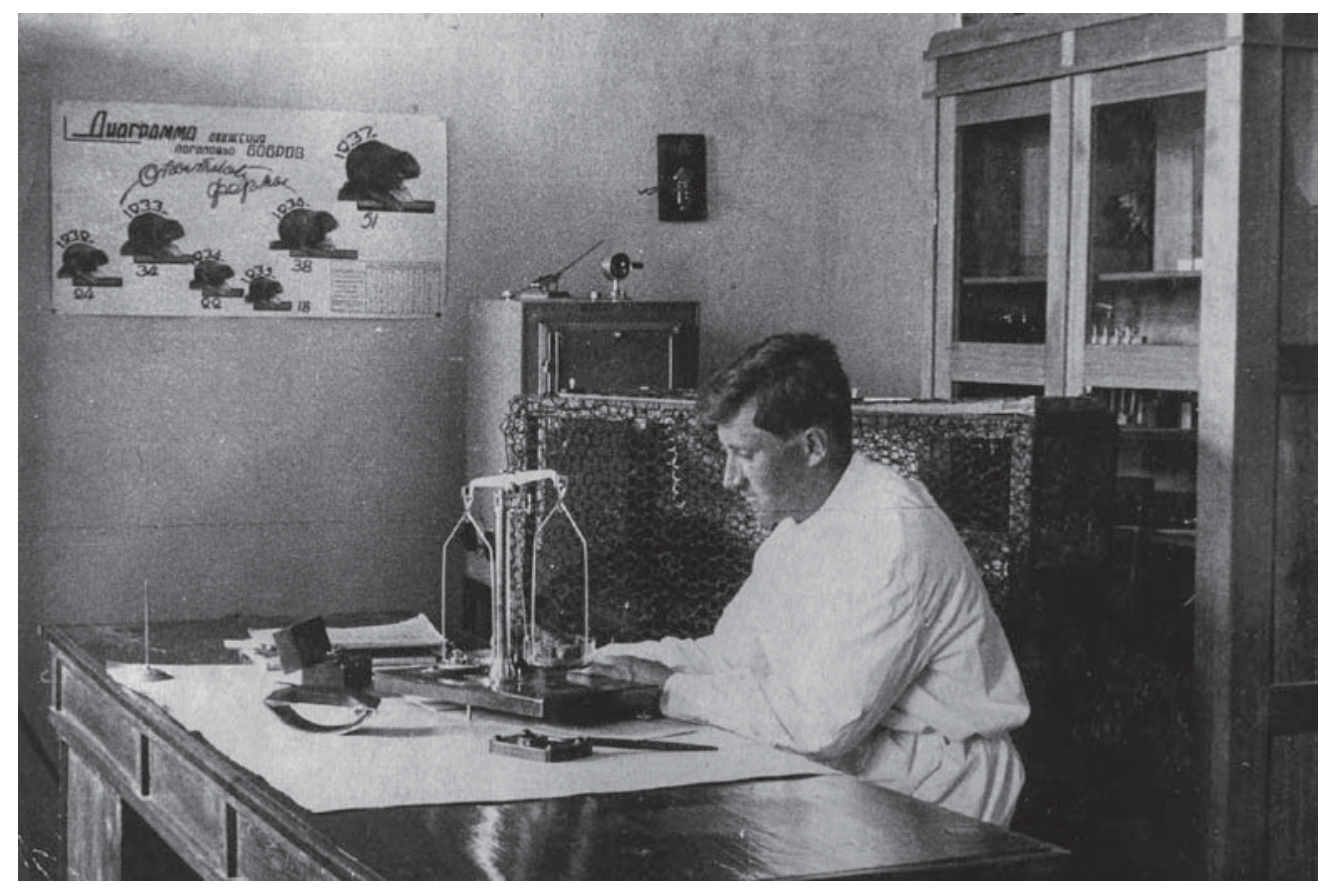

Fig. 10. Working days of the first head of the beaver farm L.S. Lavrov, 1930s.

\section{Development of scientific programs of beaver reproduction. Keeping and breed- ing of beavers in captivity}

In 1932, an experimental beaver nursery was created in the Voronezhsky Nature Reserve. It was used to keep beavers during reintroduction activities and to investigate the beaver biology in general. The first 26 beavers kept in captivity were captured in the waters of the Voronezhsky Nature Reserve and placed in openair cages. In 1934, a pair of Voronezh beavers successfully bred in captivity for the first time. Since that time, the development of a science-based program investigating breeding of caged beavers and a comprehensive study of beaver biology began.

The establishment of the beaver nursery at the Voronezhsky Nature Reserve is inextricably connected with Lavrov's presence at the reserve. The first head of the beaver nursery was Leonid S. Lavrov. He gave 56 years of his life to the Voronezhsky Nature Reserve and to the study of the biology and ecology of beavers, and their care and breeding in captivity. In 1954, he successfully defended his dissertation "Biological and zootechnical substantiation of beaver breeding on a farm", under the supervision of the famous biologist professor I.I. Barabash-Nikiforov.

From the mid-1950s until 1978, Lavrov's wife, Nadezhda Lavrova worked in the nursery. In the 1980s, she was the head of the beaver nursery. Their son Vladimir L. Lavrov continued his parents' work. He has been conducting scientific and zoological work in the beaver nursery for more than 35 years.
Investigations into captive breeding were conducted in the beaver nursery since its formation. Decisions on which beavers would be kept in captivity included selection of animals with a friendly nature (non-aggressive), and those who well-accustomed to people. In 1938, L.S. Lavrov published the first results of the study of reproductive biology of beavers in captivity in his paper "Experience of cage breeding of European beavers". Later these studies were continued and extended (Lavrov, 1948b, 1954; Lavrova \& Lavrov, 1986; and other papers). These studies were devised methods for breeding captive beavers for the purpose of obtaining valuable fur and felt, as well as castoreum for practical uses (Lavrov, 1960b). Researchers developed diets for beavers in captivity and researched the best combination of feed (Kurazhkovsky \& Krinitsky, 1956).

At first, animals were kept in open-air cages on the banks of the Usman River. In total, seven various systems of animal management developed by L.S. Lavrov were approved. Based on B.B. Belyavskaya's research in the 1950s, there were biological and zoological reasons for the method of raising wild young beavers that were orphaned as a group. She confirmed that it was possible to keep immature beavers in large group before they reached sexual maturity. During all the years that the beaver nursery was active, 1,390 beavers were born at the Voronezhsky Nature Reserve.

Currently, beaver nursery at the Voronezhsky Nature Reserve contains up to 50 animals. This is the minimal optimal number to maintain a viable beaver population to create breeding pairs, produce annual offspring, and conduct research into breeding captive beavers. Over the past 80 years, there have been ten 


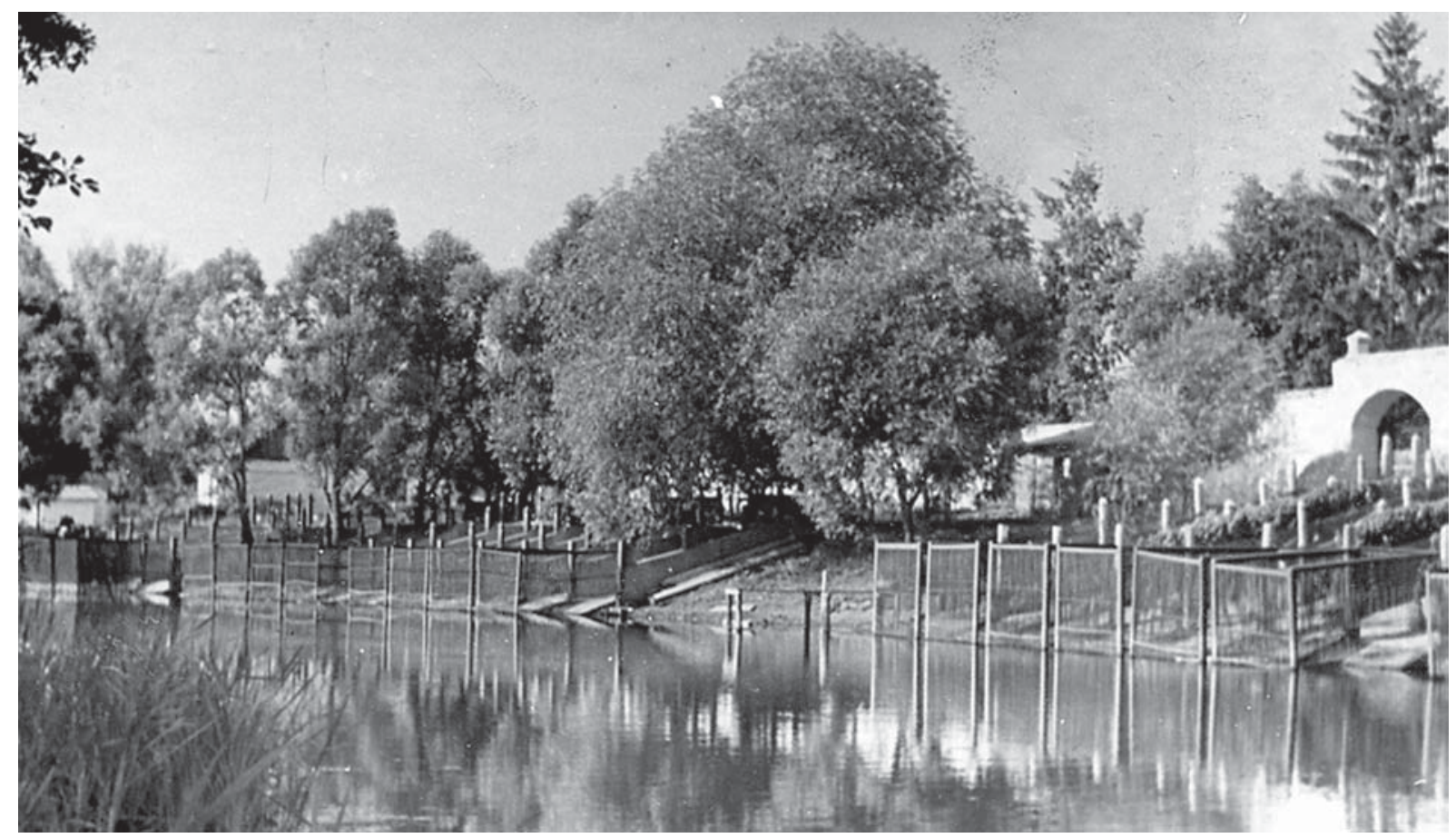

Fig. 11. Riverside open-air cages for captive beavers, 1950s.

generations of beavers born and raised at the beaver nursery. In the nursery, researchers bred "semi-wildsemi-tame" beavers that were adapted to life in captivity.

The reserve staff participated in research expeditions to study the beaver and its dispersal activities in other regions of the country and abroad. From these research trips, all existing subspecies of the beaver were brought to the nursery and kept in captivity. Studying these animals allowed L.S. Lavrov to summarize data on the taxonomy of beavers in the monograph "Beavers of Palearctic" (1981). He compiled a collection of described subspecies of beavers, which currently is demonstrated at the museum of the reserve.

\section{Research related to the study of the biol- ogy, physiology and anatomy of the beaver, its diseases and parasites}

By the time the beaver nursery was created at the Voronezhsky Nature Reserve the Eurasian beaver as a species was not well-studied. Since 1932, a comprehensive research program began related to the study of anatomy, physiology, and general biology of beavers, its diseases and parasites. Concurrently, methods of treatment and prevention of these diseases were developed. These studies were conducted throughout the entire tenure of the beaver nursery, a period of over 80 years. The most significant scientific results were obtained in the beaver nursery from the 1950s to the 1970s. Most studies were the first of their kind and involved cooperation with leading scientific institu- tions within the USSR. Results of these scientific works were published in Proceedings of the Voronezhsky Nature Reserve and in proceedings of meetings about the beaver in from 1948 until 1997. The following topics were studied for the first time in the Voronezhsky Nature Reserve: anatomical structure of the musculoskeletal of beavers, the structure of the circulatory system and blood characteristics, structural peculiarities of the gastrointestinal tract, tissue histology, and nervous and reproductive systems. Andreeva E.G., Katsnelson Z.S., Orlova I.I., Elpidin V.V., Nikulin V.N., Shvedova A.I., Strebkov M.M., Ilyin M.M., conducted this research which was published in the Proceedings of the Voronezh Nature Reserve in 1954, 1956, 1957, and 1974. Ivanova T.M., Torgun P.M., Voineak V.I., Sukhov A.M., Prasolov A.I. studied the functioning of the internal secretion glands, seasonal cyclical activity of sex glands, and the seasonal reproductive cycle of beavers (Proceedings of the Voronezh Nature Reserve, 1974).

Many scientists studied diseases of beavers in natural environments, and while beavers were in the captive-breeding. All these studies were conducted for the first time in the Voronezhsky Nature Reserve. In 1940, professor I.V. Orlov, a famous specialist in this field, laid the foundation of the study of parasitic diseases of beavers. He discovered that intensive infection with helminthes results in the death of an animal and was the first to give a summary of parasitic worms found in beavers. These studies were conducted jointly with Moskalev B.S., Pavlov A.V., and Romashov V.A. (see Proceedings of the Voronezh State Reserve, 1953, 1954). Additionally, Dubinina E.V. described 12 new species of ectoparasites (mites) of beavers. 




Fig. 12. Examination of young beavers. L.S. Lavrov, 1950s.

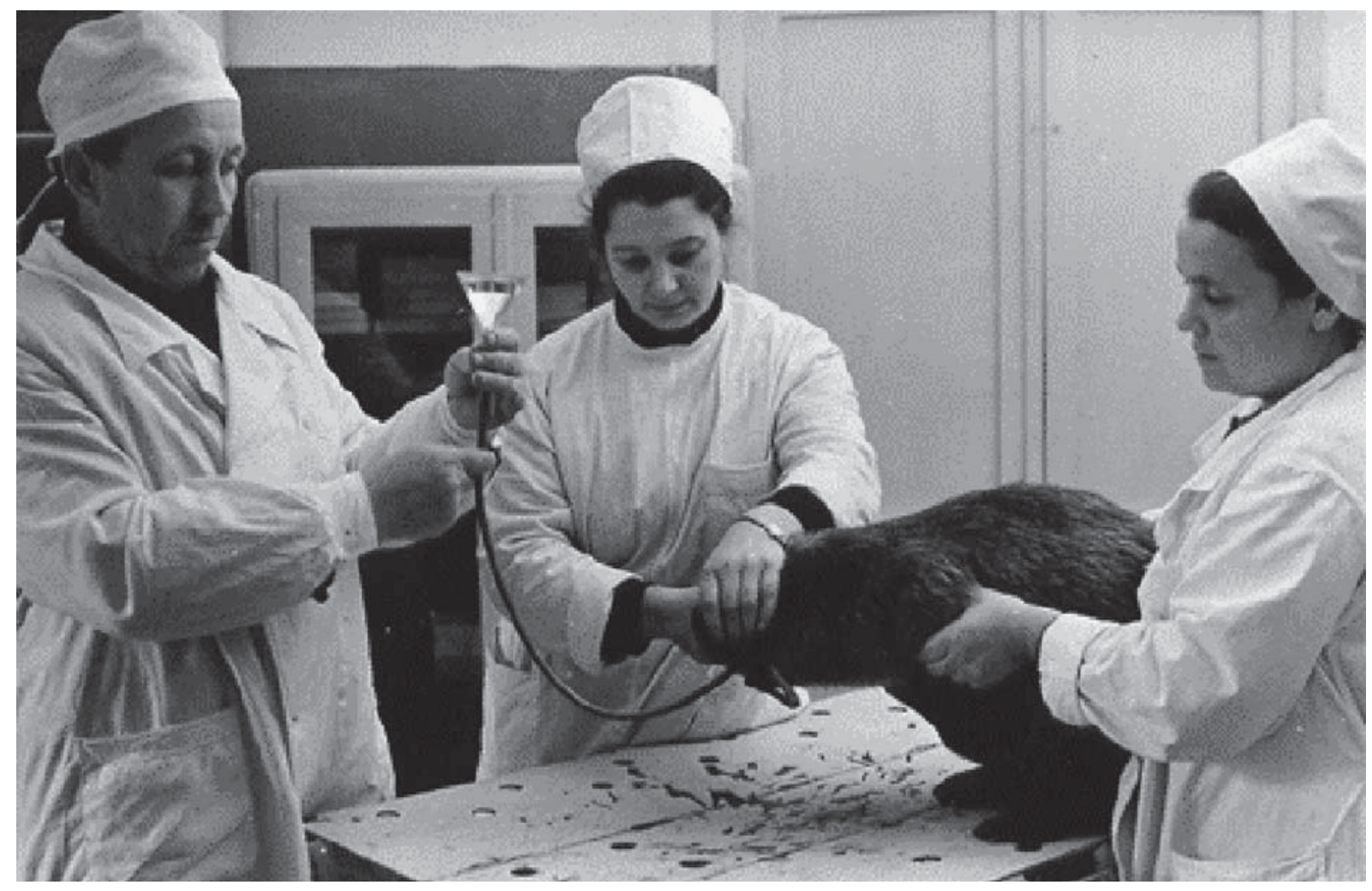

Fig. 13. Dehelmintization. Veterinary and parasitological laboratory. Dr. V.A. Romashov, veterinary assistant A.A. Bahareva and worker M.S. Parinova, 1970s. 


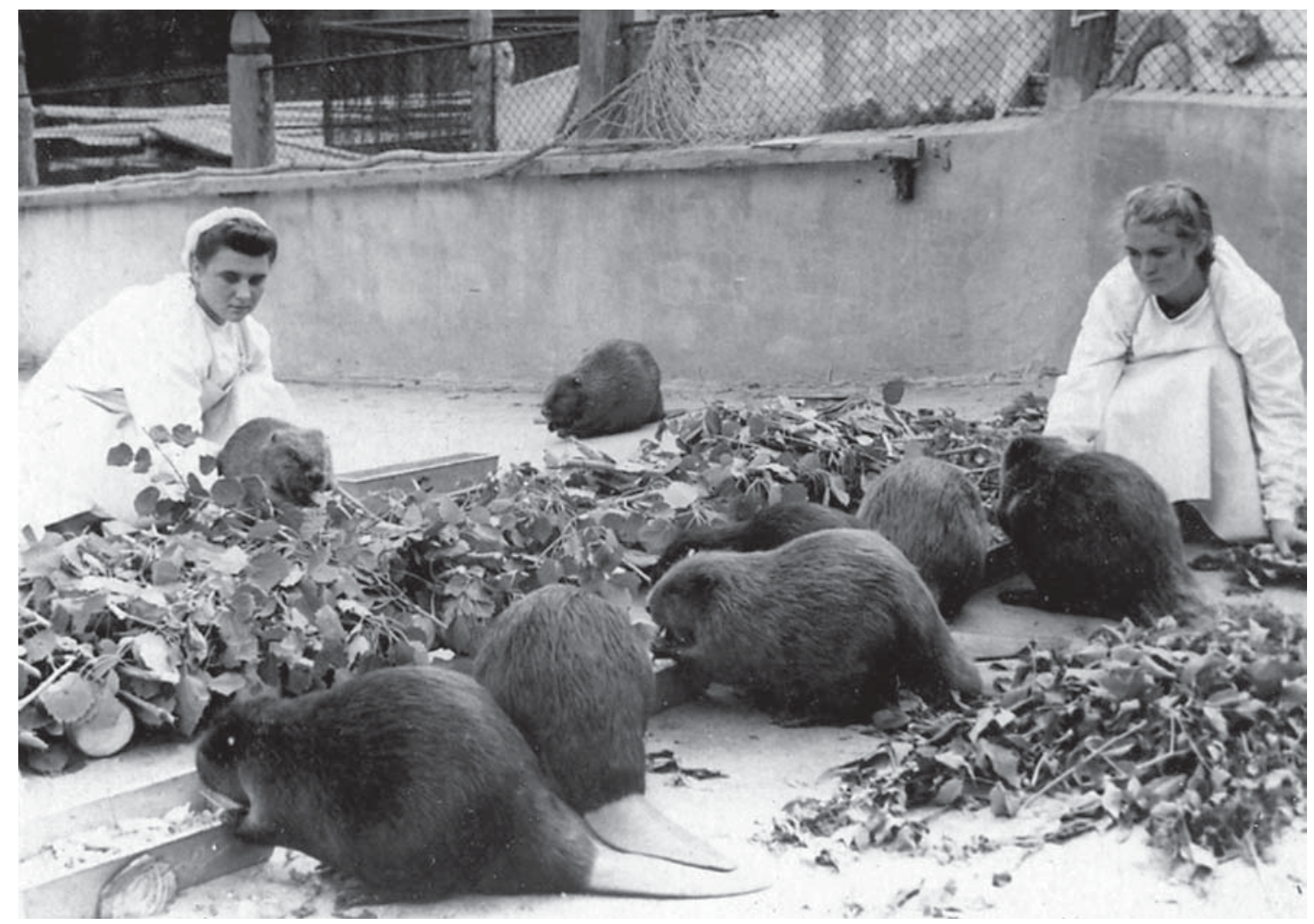

Fig. 14. Site of for keeping groups of captive beaver, 1950s.

Within the beaver nursery, many infectious diseases of beavers were studied. In turn, scientists prepared methods of prevention and treatment of these diseases. They also developed special vaccines. Borisov A.M., Tishchenko Ya.I., Tsion R.A., Romashov V.A., Shitov K.A., Chervanev V.A. and other researchers published the results of this work in the Proceedings of the Voronezhsky Nature Reserve in 1948, 1953, 1954, 1956, and 1975.

Norms, principles and methods developed in the Veterinary and Parasitological Laboratory of the Reserve from the 1950s until the 1960s were taken as a basis for diagnostic, medical, and preventive work with beavers in the beaver nursery. The laboratory was founded in 1952 by V.A. Romashov. He collected extensive helminthological data from beavers from different regions of the country. These studies became the basis for his doctoral dissertation. Professor Vitali A. Romashov developed and put into practice the measures to improve the health of animals at various helminthosis (Romashov, 1956; Rational use of the Eurasian beaver in the USSR, 1973). In 2015, long-term scientific data on helminthes of beavers were generalized in the monograph by Boris V. Romashov. So far, thanks to scientific studies of the Voronezhsky Nature Reserve, over 40 beaver diseases of infectious and noninfectious etiology have been detected.

The beaver nursery of the Voronezhsky Nature Reserve has been open for tourists since its foundation. Experience of the reserve staff allows the reserve to keep up to 50 animals in conditions close to those found in nature. The beaver nursery is doing public outreach and educational programming.

By the early 1980s, the Voronezhsky Nature Reserve essentially completed the mission for which it was created. Eurasian beaver populations have been restored in a wide range of natural habitats. The beaver is again a hunting resource in Russia, Belarus and many other countries (see paper of V. Safonov in this issue of RJT). Currently, the beaver population in Russia exceeds 500 thousand animals. Half of them originate from Voronezh area.

From 1948 to 1989 , seven all-USSR scientificallybased conferences and meetings on beavers were held in the Voronezhsky Nature Reserve. Their results were published in Abstract books.

Historically, the Voronezhsky Nature Reserve played a leading role in the conservation and restoration of beavers on the Eurasian continent. This legacy continues today. Currently, there are many beaver studies being conducted at the Reserve.

\section{References}

Dezhkin V.V., Dyakov Yu.V. \& Safonov V.G. 1986. [Beaver]. Moscow: Agropromizdat. 256 p. [in Russian].

Dezhkin V.V. \& Zharkov I.V. 1960. [Results of resettlement of Eurasian beavers in order to restore their number and habitat in the USSR] // [Proceedings of the Voronezhsky 
State Nature Reserve]. Vol.9.P.3-36 [in Russian].

Dezhkin V.V., Zharkov I.V., Lavrov L.S. \& Romashov V.A. 1960. [Keeping, transportation and release of river beavers (a practical grant)]. Lipetsk: Lipetskoe Knizhnoe Izdatelstvo. 88 p. [in Russian].

Dyakov Yu.V. 1975. [Beavers of the European Part of the Soviet Union (Morphology, Ecology, Ways and Methods of Economic Use)]. Moscow: Moskovskii Rabochii. 480 p. [in Russian].

Halley D.J. \& Rosell F. 2002. The beaver's reconquest of Eurasia: status, population development and management of conservation success // Mammal Review. Vol.32. P.153-178.

Halley D.J., Rosell F. \& Saveljev A. 2012. Population and distribution of Eurasian beaver (Castor fiber) // Baltic Forestry. Vol.18. P.168-175.

Khlebovich W.K. 1938a. [Information on ecology of the Eurasian beaver in the Voronezhsky Nature Reserve] // [Proceedings of the Voronezhsky State Nature Reserve]. Vol.1. P.43-144 [in Russian].

Khlebovich W.K. 1938b. [Expedition results on inspection and quantitative recording of beavers in the Voronezh River basin in 1934] // [Proceedings of the Voronezhsky State Nature Reserve]. Vol.1. P.145-170 [in Russian].

Khlebovich W.K. 1938c. [Experience of genetic analysis of beaver coloration] // [Proceedings of the Voronezhsky State Nature Reserve]. Vol.1. P.201-211 [in Russian].

Kurazhkovsky Yu.N. \& Krinitsky V.V. 1956. [Chemistry of foodstuff and study of herbivorous animal nutrition] // [Proceedings of the Voronezhsky State Nature Reserve]. Vol.6. P.43-60 [in Russian].

Lavrov L.S. 1938. [Experience of cage breeding of Eurasian beavers] // [Proceedings of the Voronezhsky State Nature Reserve]. Vol.1. P.171-199 [in Russian].

Lavrov L.S. 1948a. [Catching, Transportation and Release of Beavers. Instruction]. Moscow. 64 p. [in Russian].

Lavrov L.S. 1948b. [Some hereditary features of Voronezh beavers] // [Proceedings of the Voronezhsky State Nature Reserve]. Vol.2. P.129-154 [in Russian].

Lavrov L.S. 1953. [Age measurement of Eurasian beavers] // [Proceedings of the Voronezhsky State Nature Reserve]. Vol.4. P.77-84 [in Russian].

Lavrov L.S. 1954. [Biological and zootechnical grounding of breeding of beavers on a farm] // [Proceedings of the Voronezhsky State Nature Reserve]. Vol.5. P.7-25 [in Russian].

Lavrov L.S. 1956. [Revisiting characteristics of population of beavers from the Voronezh Nature Reserve] // [Proceedings of the Voronezhsky State Nature Reserve]. Vol.6. P.5-11 [in Russian].

Lavrov L.S. 1960a. [Age and sex features of the structure of a beaver skull (C. fiber vistulanus Matschie)] // [Proceedings of the Voronezhsky State Nature Reserve]. Vol.9. P.145-155 [in Russian].

Lavrov L.S. 1960b. [Vital obtaining of castoreum] // [Proceedings of the Voronezhsky State Nature Reserve]. Vol.9. P.227-232 [in Russian].

Lavrov L.S.1969a. [Native populations of Eurasian beavers in Eurasia, their condition, significance and ways of protection] // [Proceedings of the Voronezhsky State Nature Reserve]. Vol.6. P.168-177 [in Russian].

Lavrov L.S. 1969b. [Biotechnical activities on a beaver farm] // [Proceedings of the Voronezhsky State Nature Reserve]. Vol.16. P.219-232 [in Russian].
Lavrov L.S. 1981. [Beavers of Palearctic]. Voronezh: Voronezh University Press. 272 p. [in Russian].

Lavrov L.S. \& Nikolaev A.G. 1980. [Ways and means to improve the performance of beaver habitats and the quality of the population] // [Principles of Rational Planning and Ways of Intensification of Use of the Beavers. Abstracts of $6^{\text {th }}$ All-USSR Conference on the beavers]. Voronezh Nature Reserve. P.57-59 [in Russian].

Lavrova N.I. \& Lavrov V.L. 1984. [Zootechnical analysis of conditions of beaver keeping in various open-air cages] // [Scientific Bases of Beaver Breeding]. Voronezh. P.7581 [in Russian].

Moskalev B.S. \& Orlov I.V. 1953. [Dynamics of helminthosis of Eurasian beavers of the Voronezh Nature Reserve // [Proceedings of the Voronezhsky State Nature Reserve]. Vol.4. P.98-107 [in Russian].

Nikolaev A.G. 1980. [Development processes of beaver populations, sizes and methods of their exploitation] // [Principles of Rational Planning and Ways of Intensification of Use of the Beavers. Abstracts of $6^{\text {th }}$ All-USSR Conference on the beavers]. Voronezh Nature Reserve. P.5657 [in Russian].

Nikolaev A.G.1997. [Long-term dynamics of the number of beavers of the Voronezh Nature Biosphere Reserve] // [Proceedings of the Voronezhsky State Nature Reserve]. Vol.22. P.81-98 [in Russian].

Orlov I.V. \& Romashov V.A. 1954. [Echinostomatidoses of Eurasian beavers] // [Proceedings of the Voronezhsky State Nature Reserve]. Vol.5. P.64-69 [in Russian].

Poyarkov V.S. 1953. [Basics of beaver management (biotechnical arrangements)] // [Proceedings of the Voronezhsky State Nature Reserve]. Vol.4. P.13-50 [in Russian].

Romashov V.A. 1960. [Experience of recovery of Eurasian beavers from stichorchosis by eliminating intermediate hosts of the causative agent of helminthosis] // [Proceedings of the Voronezhsky State Nature Reserve]. Vol.9. P.201-213 [in Russian].

Romashov V.A. 1980. [Recommendations About Fight with Stichorchosis and Travassosiosis at a Keeping and Release of Beavers]. Voronezh. 6 p. [in Russian].

Romashov B.V. 2015. [Helminthes of Beavers: Castor fiber and C. canadensis]. Voronezh: Voronezh SAU Press. 214 p. [in Russian].

Zharkov I.V. 1956. [About the effect of winter flooding on Eurasian beavers] // [Proceedings of the Voronezhsky State Nature Reserve]. Vol.6. P.29-34 [in Russian].

Zharkov I.V. 1960. [Results and challenges of resettlement of the Eurasian beaver in the RSFSR] // [Proceedings of the Voronezhsky State Nature Reserve]. Vol.11. P.5-18 [in Russian].

Zharkov I.V. 1961. [Results of resettlement of Eurasian beavers in order to restore their number and habitat in the USSR] // [Proceedings of the Voronezhsky State Nature Reserve]. Vol.12. P.5-23 [in Russian].

Zharkov I.V. 1969a. [Results of resettlement of Eurasian beavers in the USSR] // [Proceedings of the Voronezhsky State Nature Reserve]. Vol.16. P.10-51 [in Russian].

Zharkov I.V. 1969b. [Population dynamics of Eurasian beavers in places of re-acclimatization] // [Proceedings of the Voronezhsky State Nature Reserve]. Vol.16. P.157167 [in Russian].

Zharkov I.V. 1975. [About the structure of beaver population] // [Proceedings of the Voronezhsky State Nature Reserve]. Vol.21. P.91-96 [in Russian]. 